\title{
AXIAL PARENCHYMA
}

\section{General comments:}

When identifying an unknown, use the most obvious type of parenchyma pattern first and then the less evident type or types. Be sure to use a broad field of view when determining the predominant parenchyma pattern(s) from the transverse section. Various combinations of the three general types (Apotracheal, Paratracheal, and Banded) described below may be present in a given wood.

\section{Axial parenchyma absent or extremely rare}

\section{Definition:}

Axial parenchyma absent or extremely rare = as per feature descriptor, fig. 83, e.g., Berberidaceae, Punicaceae, Violaceae, Homalium foetidum, Scottellia coriacea (Flacourtiaceae), Sonneratia spp. (Sonneratiaceae).

\section{Comment:}

It is necessary to study longitudinal sections in combination with transverse sections to be sure axial parenchyma is absent or extremely rare (i.e., very difficult to find; only a few strands per section). This feature may be used in combination with 'axial parenchyma scanty paratracheal' (feature 78) and/or 'axial parenchyma diffuse' (feature 76), if, despite the scarcity of parenchyma strands, the distribution is clear.

\section{APOTRACHEAL AXIAL PARENCHYMA}

76. Axial parenchyma diffuse

77. Axial parenchyma diffuse-in-aggregates

\section{Definitions:}

Apotracheal axial parenchyma $=$ axial parenchyma not associated with the vessels.

Axial parenchyma diffuse $=$ single parenchyma strands or pairs of strands distributed irregularly among the fibrous elements of the wood, fig. 84, e.g., Aspidosperma polyneuron (Apocynaceae), Alnus glutinosa (Betulaceae), Goupia glabra (Celastraceae), Cornus mas (Cornaceae), Apodytes dimidiata (Icacinaceae), Crataegus spp. (Rosaceae), Santalum album (Santalaceae).

Axial parenchyma diffuse-in-aggregates = parenchyma strands grouped into short discontinuous tangential or oblique lines, fig. 85, e.g., Durio spp. (Bombacaceae), Hura crepitans (Euphorbiaceae), Ongokea gore, Strombosia pustulata (Olacaceae), Agonandra brasiliensis (Opiliaceae), Dalbergia stevensonii (Papilionaceae), Pterospermum spp. (Sterculiaceae), Tilia spp. (Tiliaceae). 

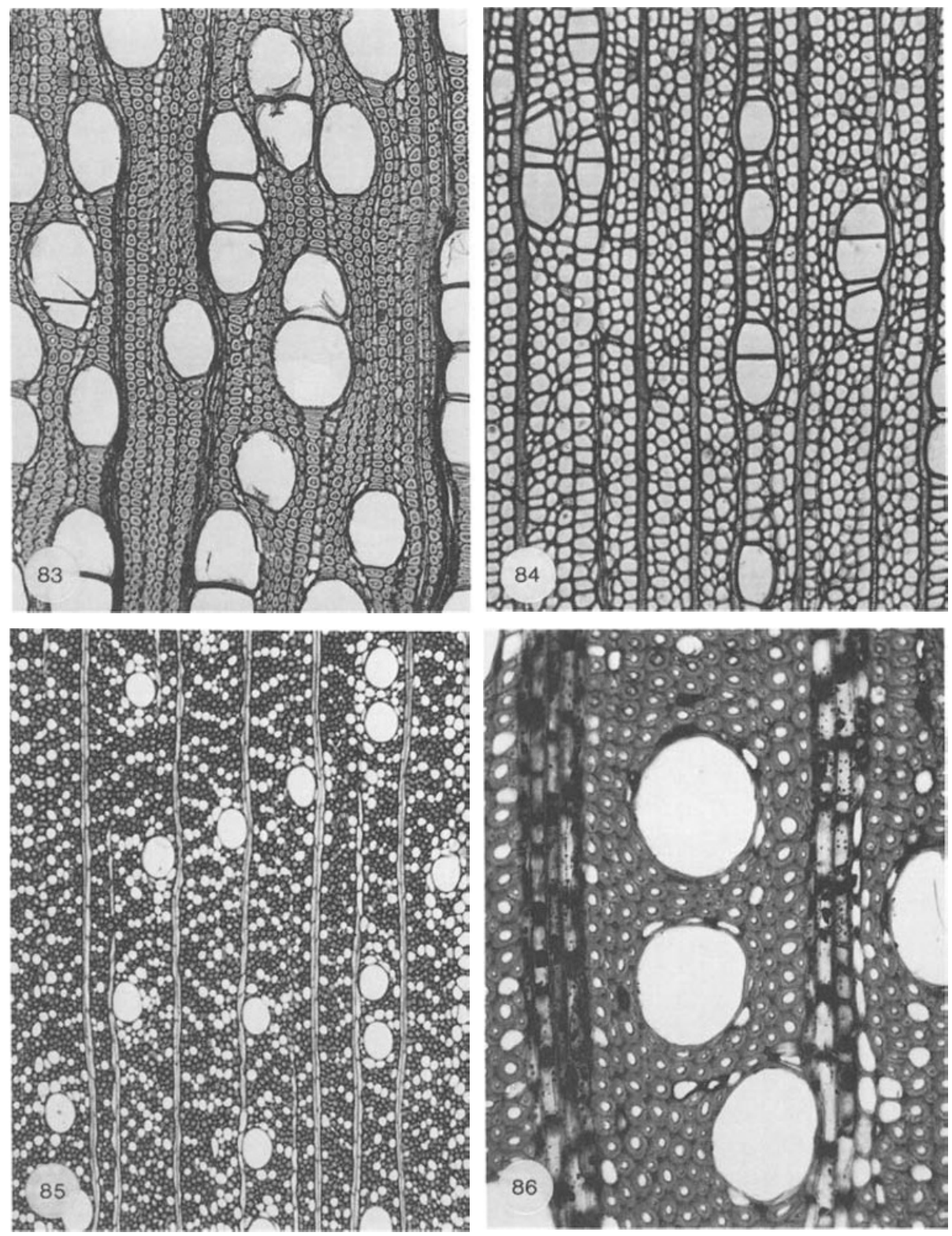

Fig. 83. Axial parenchyma absent or extremely rare (feature 75 ), Homalium foetidum, $\times 75$. Fig. 84. Axial parenchyma diffuse (feature 76), Alnus glutinosa, $\times 115$. - Fig. 85. Axial parenchyma diffuse-in-aggregates (feature 77), Agonandra brasiliensis, $\times 45$. - Fig. 86. Axial parenchyma scanty paratracheal (feature 78), and also scanty diffuse (feature 76), Dillenia pulcherrima, $\times 115$. 


\section{Comments:}

Because there is a continuous range from parenchyma extremely rare, diffuse, diffuse-inaggregates, to parenchyma in narrow bands (feature 86 ) or scalariform (feature 88), for some taxa it will be necessary to record more than one feature for apotracheal parenchyma. Diffuse and diffuse-in-aggregates frequently occur in combination. Record (1944) referred to diffuse-inaggregates parenchyma as reticulate. This list does not follow that usage, but uses reticulate to describe a type of banded parenchyma, see feature 87.

Cautions: Although by definition apotracheal parenchyma is not associated with vessels, woods with abundant diffuse or diffuse-in-aggregate parenchyma may exhibit several strands touching the vessels. Such random contacts should not be recorded as paratracheal parenchyma.

Apotracheal diffuse parenchyma sometimes occurs primarily near the rays ('ray adjacent parenchyma' of Carlquist 1988), and should not be confused with sheath cells in rays (feature $110)$.

\section{PARATRACHEAL AXIAL PARENCHYMA}

78. Axial parenchyma scanty paratracheal

79. Axial parenchyma vasicentric

80. Axial parenchyma aliform

81. Axial parenchyma lozenge-aliform

82. Axial parenchyma winged-aliform

83. Axial parenchyma confluent

84. Axial parenchyma unilateral paratracheal

\section{Definitions:}

Axial parenchyma paratracheal $=$ axial parenchyma associated with the vessels or vascular tracheids; types of paratracheal parenchyma are scanty paratracheal, vasicentric, aliform (subtypes: lozenge-aliform, winged-aliform), confluent, and unilateral paratracheal.

Axial parenchyma scanty paratracheal $=$ occasional parenchyma cells associated with the vessels or an incomplete sheath of parenchyma around the vessels, fig. 86, e.g. Pistacia vera (Anacardiaceae), Sclerolobium spp. (Caesalpiniaceae), Dillenia pulcherrima (Dilleniaceae), Erythroxylum mannii (Erythroxylaceae), Laurus nobilis (Lauraceae).

Axial parenchyma vasicentric $=$ parenchyma cells forming a complete circular to oval sheath around a solitary vessel or vessel multiple, figs. 87, 88, e.g. Tachigali myrmecophylla (Caesalpiniaceae), Octomeles sumatrana (Datiscaceae), Phoebe porosa (Lauraceae), Khaya grandifoliola (Meliaceae), Anadenanthera spp., Enterolobium cyclocarpum, Piptadeniastrum africanum (Mimosaceae), Olea europaea (Oleaceae).

Axial parenchyma aliform = parenchyma surrounding or to one side of the vessel and with lateral extensions. For examples see the two subtypes below.

Axial parenchyma lozenge-aliform = parenchyma surrounding or to one side of the vessels with lateral extensions forming a diamond-shaped outline, fig. 89, e.g., Albizia lebbek, Parkia gigantocarpa (Mimosaceae), Artocarpus chaplasha (Moraceae), Microberlinia brazzavillensis, Ormosia flava, Vatairea spp. (Papilionaceae), Qualea rosea (Vochysiaceae). 

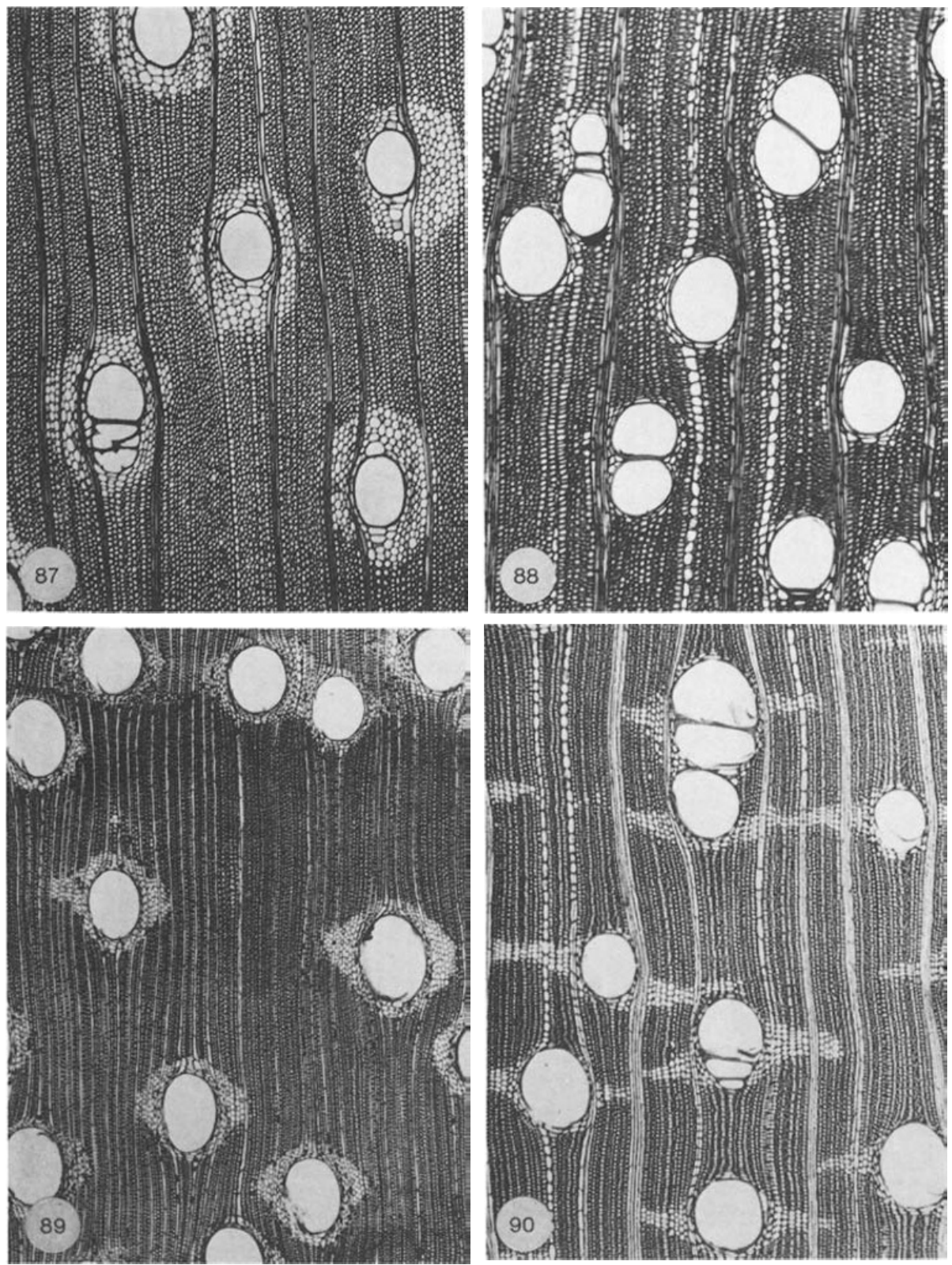

Figs. 87 \& 88. Axial parenchyma vasicentric (feature 79). - 87: Parenchyma sheath broad, Piptadeniastrum africanum, $\times 26 .-88$ : Parenchyma sheath narrow, Khaya grandifoliola $\times 45$. - Fig. 89. Axial parenchyma lozenge-aliform (features 80 and 81), Microberlinia brazzavillensis, $\times 29$. - Fig. 90. Axial parenchyma winged-aliform (features 80 and 82 ), Brosimum rubescens, $\times 45$. 

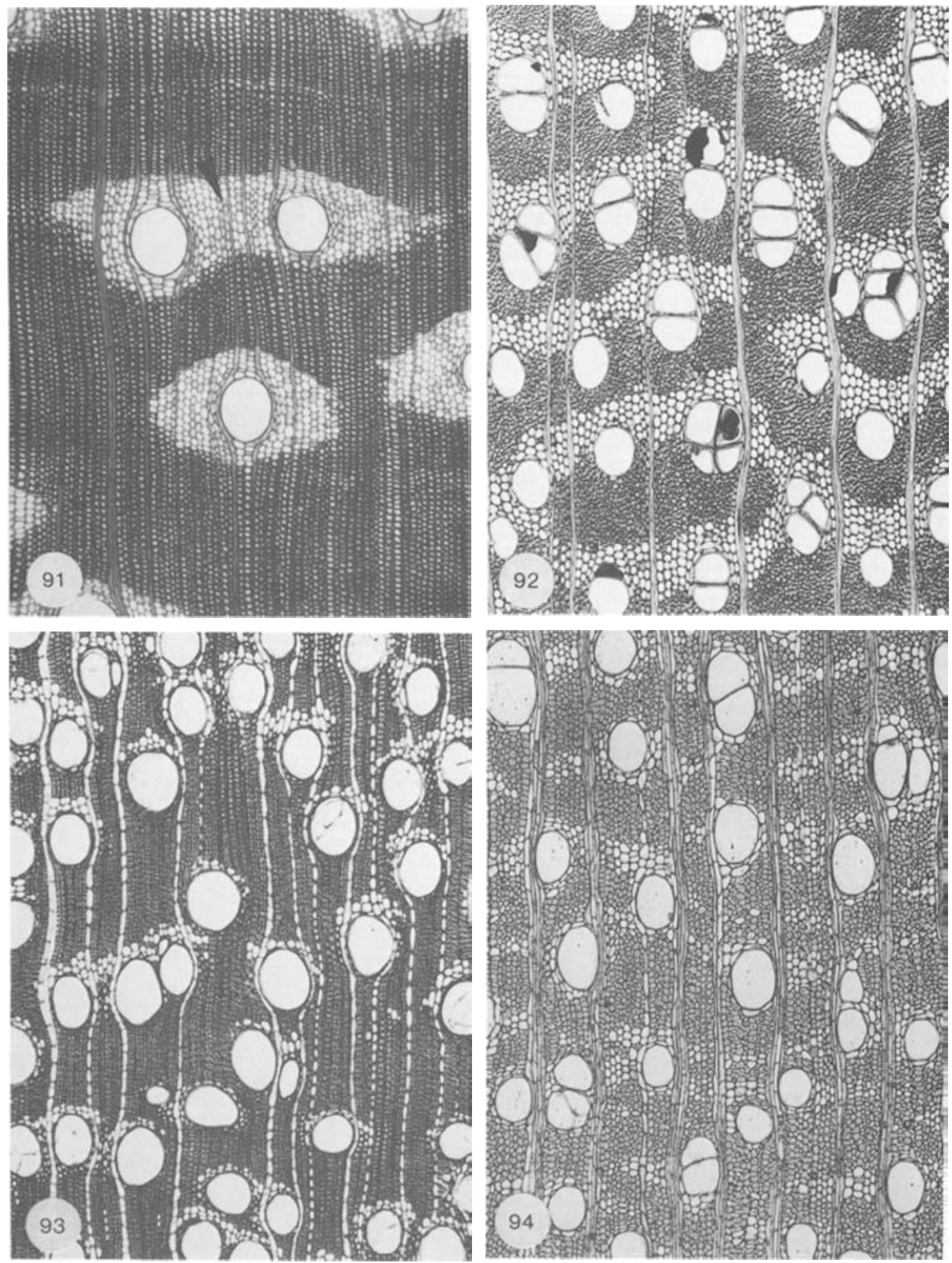

Figs. 91 \& 92. Axial parenchyma confluent (feature 83). - 91: Parkia pendula (arrowhead, note also features 80 and 81 , parenchyma lozenge-aliform), $\times 36 .-92$ : Peltogyne confertiflora (note also feature 84 , unilateral parenchyma), $\times 45$. - Fig. 93. Axial parenchyma unilateral paratracheal (feature 84), Caraipa grandiflora, $\times 45$. - Fig. 94. Axial parenchyma predominantly paratracheal, Garcinia latissima (note also features 80 , aliform, and 83 , confluent), $\times 45$. 
Axial parenchyma winged-aliform = parenchyma surrounding or to one side of the vessels with the lateral extensions being elongated and narrow, fig. 90, e.g., Jacaranda copaia (Bignoniaceae), Terminalia superba (Combretaceae), Brosimum spp. (Moraceae), Quassia amara (Simaroubaceae), Gonystylus spp. (Thymelaeaceae).

Axial parenchyma confluent $=$ coalescing vasicentric or aliform parenchyma surrounding or to one side of two or more vessels, and often forming irregular bands, figs. 91, 92, e.g., Kigelia africana (Bignoniaceae), Caesalpinia ferrea, Peltogyne confertiflora (Caesalpiniaceae), Marmaroxylon racemosum, Parkia pendula (Mimosaceae), Chlorophora tinctoria (Moraceae), Bowdichia nitida,Vatairea guianensis (Papilionaceae).

Axial parenchyma unilateral paratracheal = paratracheal parenchyma forming semicircular hoods or caps only on one side of the vessels and which can extend tangentially or obliquely in an aliform or confluent or banded pattern, fig. 93, e.g., Aspidosperma desmanthum (Apocynaceae), Caraipa grandiflora (Bonnetiaceae), Peltogyne confertiflora (Caesalpiniaceae), Mammea bongo (Guttiferae), Dilobeia thouarsii (Proteaceae).

\section{Comments:}

Scanty paratracheal includes what has been described in the literature as incomplete vasicentric.

Some woods have vasicentric, aliform, and confluent paratracheal parenchyma. Confluent often intergrades with banded and may be recorded or used in combination with features for band width (85-86). Feature 80, 'Axial parenchyma aliform', is included as a general category to 1) describe those woods that clearly have aliform parenchyma, but in which it is difficult to decide whether it is lozenge- or winged-aliform, and 2) allow use of information from the literature that does not differentiate between these two types. Features 81 and 82 are used in combination with feature 80 .

Feature 84 'unilateral paratracheal parenchyma' is used in combination with aliform and/or confluent when the unilateral parenchyma extends laterally or obliquely. Unilateral includes both abaxial and adaxial because generally it is not possible to distinguish between the two in a wood fragment.

Woods with several types of paratracheal parenchyma co-occurring and/or intergrading have been assigned the general descriptor 'parenchyma predominantly paratracheal' by several authors (fig. 94).

Caution: Vasicentric/vascular tracheids are often thinner-walled than ground tissue fibres, and in cross sections may be confused with axial parenchyma. Examine longitudinal sections to determine whether vasicentric/vascular tracheids or axial parenchyma surrounds the vessels. 


\section{BANDED PARENCHYMA}

85. Axial parenchyma bands more than three cells wide

86. Axial parenchyma in narrow bands or lines up to three cells wide

87. Axial parenchyma reticulate

88. Axial parenchyma scalariform

89. Axial parenchyma in marginal or in seemingly marginal bands

\section{Definitions:}

Parenchyma bands more than three cells wide = as per feature descriptor, fig. 95 , e.g., Dicorynia paraensis (Caesalpiniaceae), Entandrophragma candollei (Meliaceae), Ficus retusa (Moraceae), Lophira alata (Ochnaceae), Basyloxylon brasiliensis (Sterculiaceae), Erisma uncinatum (Vochysiaceae).

Parenchyma in narrow bands or lines up to three cells wide $=$ as per feature descriptor, figs. 96, 98, e.g., Dialium guianensis (Caesalpiniaceae), Endospermum malaccensis (Euphorbiaceae), Bertholletia excelsa (Lecythidaceae), Dysoxylum fraseranum (Meliaceae), Autranella congolensis (Sapotaceae), Hannoa klaineana (Simaroubaceae).

Parenchyma reticulate $=$ parenchyma in continuous tangential lines of approximately the same width as the rays, regularly spaced and forming a network with them. The distance between the rays is approximately equal to the distance between the parenchyma bands, fig. 97 , e.g., Cleistopholis spp. (Annonaceae), Diospyros discolor (Ebenaceae), Bertholletia excelsa, Cariniana spp., Couratari guianensis, Eschweilera spp. (Lecythidaceae).

Parenchyma scalariform = parenchyma in fairly regularly spaced fine lines or bands, arranged horizontally or in arcs, appreciably narrower than the rays and with them producing a ladder-like appearance in cross section. The distance between the rays is greater than the distance between parenchyma bands, figs. 99, 100, e.g., Anisophyllea spp. (Anisophylleaceae), Onychopetalum sp. and most other Annonaceae, Cardwellia sublimis, Embothrium mucronatum (Proteaceae), Rhopalocarpus spp. (Rhopalocarpaceae).

Parenchyma in marginal or in seemingly marginal bands = parenchyma bands which form a more or less continuous layer of variable width at the margins of a growth ring or are irregularly zonate, figs. 101, 102, e.g., Intsia bijuga (Caesalpiniaceae), Juglans regia (Juglandaceae), Cryptocarya moschata (Lauraceae), Liriodendron tulipifera, Michelia compressa (Magnoliaceae), Cedrela spp., Swietenia spp. (Meliaceae), Horsfieldia subglobosa (Myristicaceae).

\section{Comments:}

Parenchyma bands may be mainly independent of the vessels (apotracheal), definitely associated with the vessels (paratracheal), or both. Bands may be wavy, diagonal, straight, continuous or discontinuous (the latter often intergrading with confluent). The number of bands per $\mathrm{mm}$ varies and may be useful as a diagnostic feature in some groups. Bands over three cells wide are visible to the unaided eye. For woods with reticulate, scalariform, or marginal parenchyma, the band width (either features 85 or 86 ) also should be recorded.

In the past, some anatomists (e.g., Record 1944) have used the term reticulate for abundant diffuse-in-aggregates parenchyma with numerous short interrupted lines.

Sometimes marginal parenchyma bands are associated with axial intercellular canals. In some temperate woods there are discontinuous bands/lines of parenchyma at the growth ring margin; this condition also should be described as 'marginal'. Marginal parenchyma includes terminal and initial parenchyma, and seemingly marginal includes what has been called irregular zonate bands. 

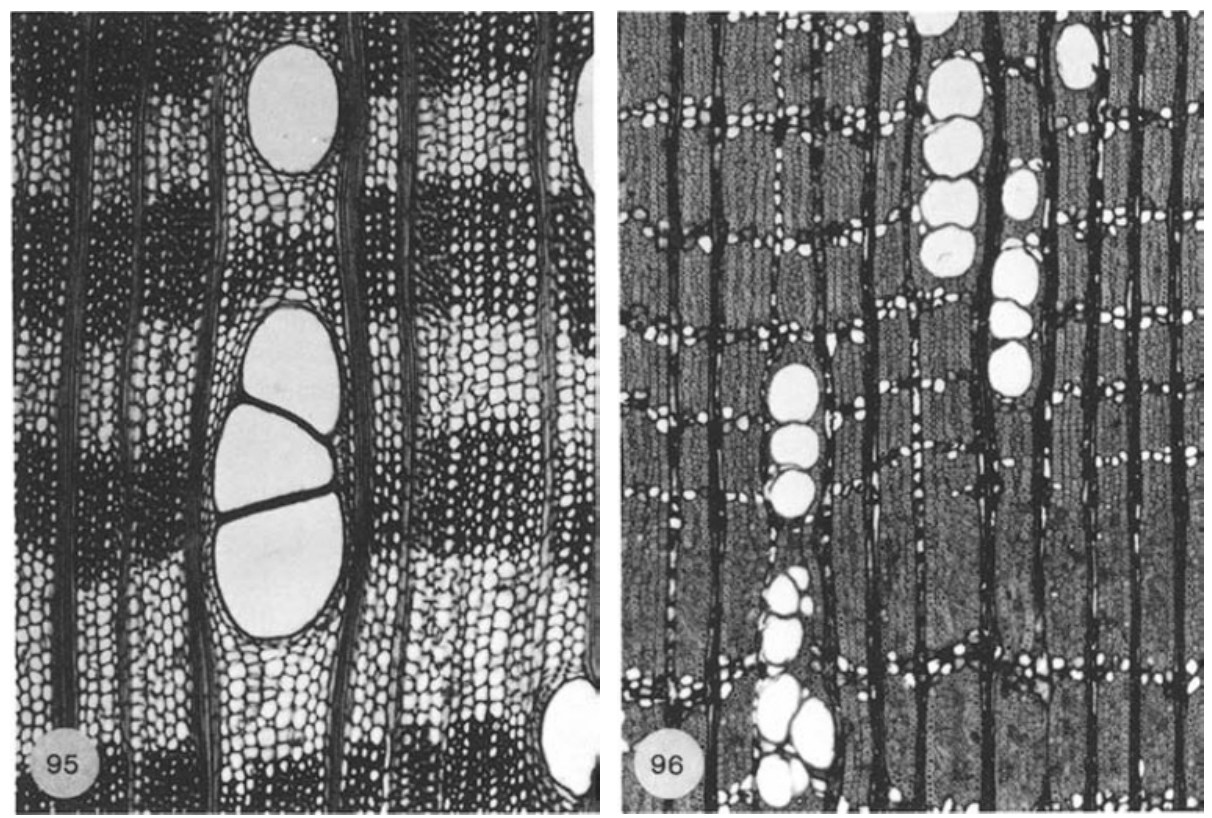

Fig. 95. Axial parenchyma in bands more than three cells wide (feature 85 ), Ficus retusa, $\times 45$. - Fig. 96. Axial parenchyma in narrow bands or lines up to three cells wide (feature 86), Autranella congolensis, $\times 45$. 

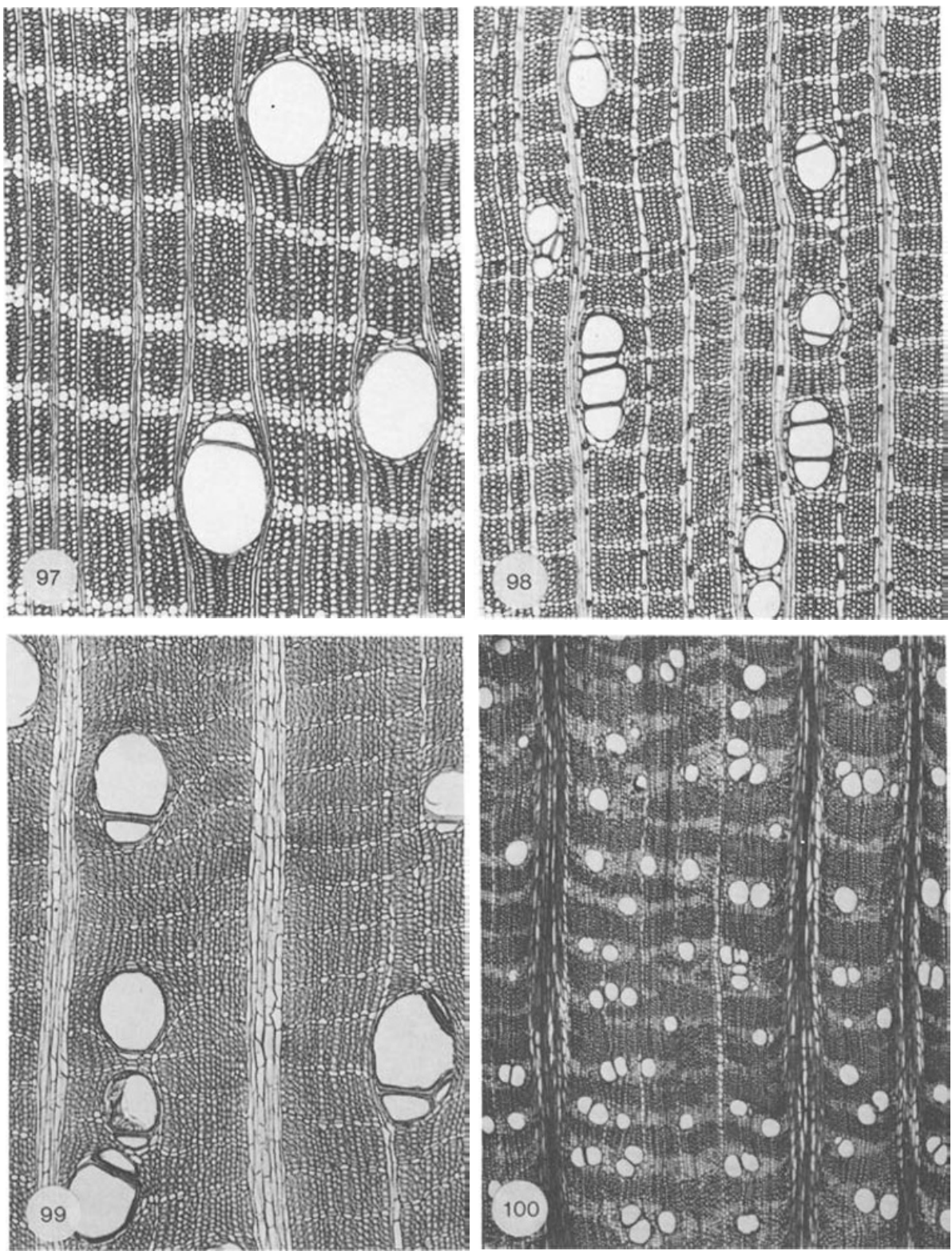

Fig. 97. Axial parenchyma reticulate (feature 87), Bertholletia excelsa (note also feature 86, parenchyma in narrow bands), $\times 45$. - Fig. 98. Axial parenchyma intermediate between reticulate and scalariform (features 87 and 88 variable), Couratari guianensis, $\times 45$. - Figs. 99 \& 100. Axial parenchyma scalariform (feature 88). -99 : Onychopetalum sp., $\times 45 .-100$ : Parenchyma bands also 'festooned', Cardwellia sublimis, $\times 15$. 

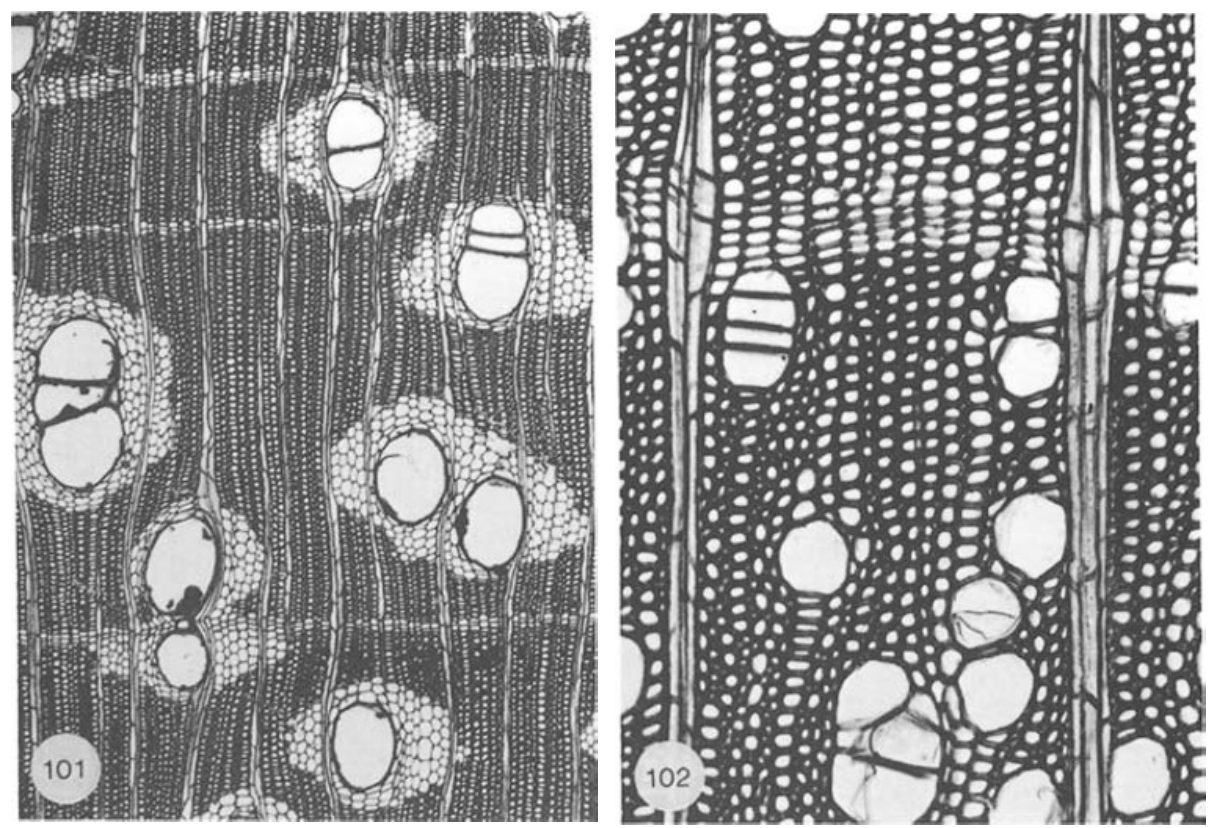

Figs. $101 \&$ 102. Axial parenchyma in marginal or seemingly marginal bands (feature 89). 101: Intsia bijuga. Note also features 80,81 (lozenge-aliform parenchyma), 83 (confluent), and 86 (narrow bands); $\times 29$. - 102: Michelia compressa $\times 45$. 


\section{AXIAL PARENCHYMA CELL TYPE/STRAND LENGTH}

90. Fusiform parenchyma cells

91. Two cells per parenchyma strand

92. Four (3-4) cells per parenchyma strand

93. Eight (5-8) cells per parenchyma strand

94. Over eight cells per parenchyma strand

Definitions:

Fusiform parenchyma = parenchyma cells derived from fusiform cambial initials without subdivisions or tip growth. In shape they resemble a short fibre, fig. 103, e.g., Capparis spp. (Capparidaceae), Aeschynomene elaphroxylon, Erythrina spp., Lonchocarpus spp. (Papilionaceae), Triplochiton scleroxylon (Sterculiaceae), Bulnesia spp., Guiacum spp., Zygophyllum spp. (Zygophyllaceae).

Parenchyma strand = a series of axial parenchyma cells formed through transverse division(s) of a single fusiform cambial initial cell.

Two cells per parenchyma strand, figs. 103, 104, e.g., Dalbergia spp., Lonchocarpus spp., Pterocarpus spp.(Papilionaceae).

Four (3-4) cells per parenchyma strand, fig. 104, e.g., Terminalia spp. (Combretaceae), Ligustrtum spp., Syringa spp. (Oleaceae), Nesogordonia spp. (Sterculiaceae).

Eight (5-8) cells per parenchyma strand, fig. 105, e.g., Nerium oleander (Apocynaceae), Macaranga spp. (Euphorbiaceae), Fraxinus spp. (Oleaceae).

Over eight cells per parenchyma strand, e.g., Bhesa spp. (Celastraceae), Lophira spp. (Ochnaceae), Minquartia spp., Tetrastylidum spp. (Olacaceae).

\section{Comments:}

Type of parenchyma, fusiform vs. strand, is determined from tangential sections. Fusiform parenchyma cells are relatively uncommon and generally occur in woods with storied structure and short axial elements. In some species, combinations of the above features occur, e.g. 'fusiform cells' and 'two cells per parenchyma strand', or 'two cells per parenchyma strand' and 'four (3-4) cells per parenchyma strand'. Strand length can differ between earlywood and latewood of the same ring, or between vessel-associated parenchyma and parenchyma which is not in contact with the vessels. Record all commonly occurring strand lengths.

Caution: Be careful not to confuse uniseriate rays or septate fibres with strand parenchyma. Do not determine number of cells per strand from chambered crystalliferous strands.

\section{Unlignified parenchyma}

\section{Definition:}

Unlignified parenchyma $=$ as per feature descriptor, fig. 106, e.g., Apeiba spp., Entelea arborescens, Heliocarpus spp. (Tiliaceae), Laportea stimulans (Urticaceae).

\section{Comment:}

Unlignified parenchyma usually occurs in broad bands, and is restricted to a small number of taxa. 

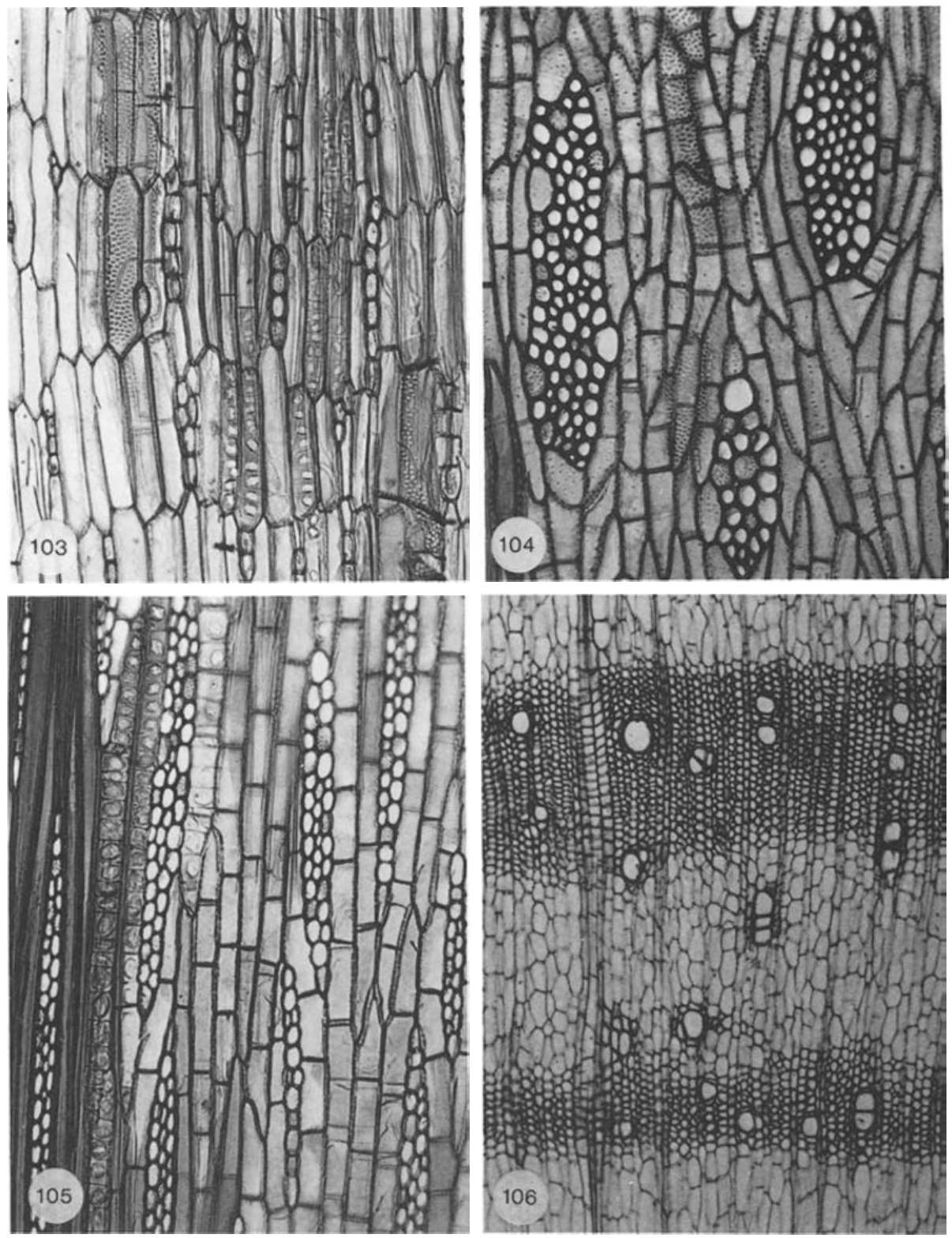

Fig. 103. Fusiform parenchyma cells (feature 90, left and right) and two cells per parenchyma strand (feature 91, left centre). Note also feature 120 (axial parenchyma storied) and feature 142 (crystals in chambered axial parenchyma). Aeschynomene elaphroxylon, $\times 115$. - Fig. 104. Two (feature 91) to four (feature 92) cells per parenchyma strand, Cordia abyssinica, $\times 115$. Fig. 105. Eight (feature 93) or over eight cells (feature 94) per parenchyma strand, Bertholletia excelsa, $\times 115$. - Fig. 106. Unlignified parenchyma (feature 95), Entelea arborescens, $\times 45$. 